\title{
Learn to Discover Pythagoras Theorem with Interactive Multimedia
}

\author{
Indra Adhitama \\ Departmen of Mathematics Education \\ Sebelas Maret University \\ Surakarta, Indonesia \\ indranisa69@gmail.com
}

\author{
Imam Sujadi \\ Departmen of Mathematics Education \\ Sebelas Maret University \\ Surakarta, Indonesia
}

\author{
Ikrar Pramudya \\ Departmen of Mathematics Education \\ Sebelas Maret University \\ Surakarta, Indonesia
}

\begin{abstract}
The difficulty of using discovery learning model in learning mathematics is the presence of abstract elements that have not been able to be understood by junior high school students. One solution of the problem is to use interactive multimedia. The purpose of this article is to find out the effectiveness of the learning model of Discovery Learning, the subject matter of Pythagoras theorem with interactive multimedia. The method used is quasi experiment. The study population was all students of grade VIII MTs Al-Furqon with samples consisting of two classes, each as an experimental class and control class. The data analysis technique used to hypothesis test is t-test. The result of this research is learning model of Discovery Learning material of Pythagoras theorem by using interactive multimedia more effectively than learning model of Discovery Learning material of Pythagoras theorem without interactive multimedia.
\end{abstract}

Keywords—Learn; Discovery Learning; Interactive Multimedia; Pythagoras Theorem.

\section{INTRODUCTION}

The achievement of mathematics learning in Indonesia is still low. This can be seen from the results of the Program for International Student Assessment (PISA), this is related to the average math skills of students in Indonesia. PISA results in 2015 Indonesia is ranked 62 out of 70 countries [1]. The achievement of mathematics learning can also be seen from the results of Trends in International Mathematics and Science Study (TIMMS) [2], Indonesia with an average score of 386 ranking 38 of 42 countries.

Many efforts made by the government in improving the quality of education in Indonesia one of them is changing the curriculum. The current curriculum is the 2013 curriculum, wherein it emphasizes learning with a scientific approach. The scientific approach must be applied at all levels of education, both primary and secondary school [3].

Application of learning model of discovery learning (DL) is one of the learning model with scientific approach [3]. The activities in learning scientific approach, among others, observing, asking, collecting, processing information, and concluded.

The DL learning model is a learning model that focuses on the process of conceptual discovery or principle, with learning DL being more meaningful and can last longer in memory [4].
The problem of DL itself when applied in learning mathematics is some students, especially teenagers still not fully able to think abstract where mathematics has many abstract elements. This is consistent with Piaget's theory of learning that junior high school students (ages 12-15) have not been fully capable of abstract thinking [5]. Junior high school students are not able to think abstract yet, but it is time to be invited or trained in abstract thinking.

One solution to the problem is the use of instructional media. This is in agreement with the results of the study [3], that the DL model with the media in its application in the class invites students to understand the concepts found in the lesson. In this article the media used computer-based interactive multimedia, because in interactive multimedia more complete. Not only images but a combination of all media such as images, animations, and so forth, thus learning becomes easier [6]. This is in accordance with the results of the study [7] that, "Multimedia lessons certainly make learning easier, especially in the fields which are more abstract and which are better understood with the help of pictures and animations". In addition interactive multimedia also has advantages that can be controlled by the user [8] [9] [10] [11] [12] [13].

The results of interviews with teachers and students show that students are less active and not interested in learning mathematics. A low interest in mathematics can lead to low student mathematics achievement. This is in line with House research results [14], which states that students who are serious or interested in learning mathematics have higher learning achievement than other students.

According to Hamalik in Arsyad [15], the use of learning media in teaching and learning can generate new desires and interests, generate motivation and stimulation of learning activities, and even bring psychological influences on students. In addition to Arsyad [15], learning media can also make students improve understanding, present data attractively and reliably, facilitate interpretation of data and condense information. In other words, the presentation of lesson materials using the media can create interesting learning, so it can spur interest and curiosity of students. 
Learning DL on the material Pythagoras theorem by using interactive multimedia has not been much in the perusal, so the author took the initiative to do so.

\section{METHOD}

This research is actually a development research ( R \& D) that aims to produce interactive multimedia products. The development model used is ADDIE. The reason for using ADDIE is because the development model is effective and widely used in product development [16]. The ADDIE development model has the following development steps: (1) Analysis, (2) Design, (3) Development, (4) Implementation, and (5) Evaluation. This article will only cover the evaluation of interactive multimedia development. The evaluation stage in development research is important to undertake, it aims to measure the effectiveness of developed media. The Evaluation Phase is a step in the ADDIE development model after the maturation stage of Anaysis, Design, Development, and Implementation [17].

The experimental method in this research is quasi experiment. The sample of the research is all students of class VIII in MTs Al-Furqon of academic year 2017/2018. Two random classes were taken to experiment and control classes. After two classes are selected, the next step is to provide a written test to the two classes (pre-test) to test the class balance by analyzing the t-test data. The goal is to know whether the experimental class and the control class are in a balanced state. If the two classes are in balance then treated. The experimental class is given learning of the Pythagoras theorem of DL model using the developed medium, while the control class is given learning of Pythagoras theorem DL model without using developed medium.

After the treatment, both classes were given a written test (post-test) to determine the effectiveness of pythagoras theorem learning with interactive multimedia using t-test data analysis. But before that, test prasarat analysis such as normality test with Lilifords test and homogeneity test with Bartlett test. The learning medium is said to be effective after the data through the t-test if $\mathrm{HO}$ is rejected [18] [19].

\section{RESULTS AND DISCUSSION}

The results of written tests (posttest) to obtain data on student mathematics learning achievement are as follows:

TABLE I. Mathematic Learning AChiEVEment Data

\begin{tabular}{lccccc}
\hline \multicolumn{1}{c}{ Class } & N & Mean & Variant & Max Score & $\begin{array}{c}\text { Min } \\
\text { Score }\end{array}$ \\
\hline Experiment & 23 & 83,36 & 210,31 & 100 & 65 \\
\hline Control & 24 & 65,67 & 255,63 & 80 & 57 \\
\hline
\end{tabular}

A. Prerequisite Analysis

Before the hypothesis test is done, the prerequisite analysis test is done first:

- Normality test
Here's a summary of the normality-test results using Lilifords.

TABLE II. NORMALITY TEST

\begin{tabular}{|c|c|c|c|c|}
\hline \multirow{2}{*}{ Class } & \multicolumn{3}{|c|}{ Normality test } & \multirow{2}{*}{ Conclusion } \\
\hline & $L_{o b s}$ & $L_{\text {table }}$ & Decision & \\
\hline Experiment & 0,069 & 0,103 & $\begin{array}{l}\mathrm{H}_{0} \text { is not } \\
\text { rejected }\end{array}$ & Normal \\
\hline Control & 0,097 & 0,102 & $\begin{array}{l}\mathrm{H}_{0} \text { is not } \\
\text { rejected }\end{array}$ & Normal \\
\hline
\end{tabular}

The result of normality test showed on the experimental learning data of experimental class with, so that $\mathrm{H}_{0}$ is accepted, so also the data of learning achievement of control class with, so that $\mathrm{H}_{0}$ is accepted. So the data of the two classes are normally distributed.

- Homogeneity Test

Here's a summary of the homogenity test results by using Bartlet test.

\begin{tabular}{lccll} 
& TABLE III. & \multicolumn{3}{c}{ HOMOGENEITY TEST } \\
\hline Test & $X^{2}{ }_{\text {obs }}$ & $X_{\text {table }}^{2}$ & Decision & Conclusion \\
\hline $\begin{array}{l}\text { Mathematic } \\
\begin{array}{l}\text { Learning } \\
\text { Achievement }\end{array}\end{array}$ & 0,202 & 3,841 & $\begin{array}{l}\mathrm{H}_{0} \text { is not } \\
\text { rejected }\end{array}$ & Homogeneous \\
\hline
\end{tabular}

Homogeneity test results show that, so $\mathrm{H}_{0}$ is accepted. So it can be concluded that both classes are homogeneous.

\section{B. Hypothesis test}

After prelayat test has been fulfilled, next is hypothesis test by using t-test data analysis. Here is a summary of the t-test results.

\begin{tabular}{cccccc} 
TABLE 4 & \multicolumn{5}{c}{ THE SUMMARY OF MATHEMATIC LEARNING } \\
& \multicolumn{5}{c}{ ACHIEVEMENT T-TEST } \\
\hline \multicolumn{1}{c}{ Class } & $\mathrm{N}$ & Average & $\mathrm{t}_{\mathrm{obs}}$ & $\mathrm{t}_{\alpha}$ & Decision \\
\hline Experiment & 23 & 83,36 & 3,215 & 2,115 & $\begin{array}{l}\mathrm{H}_{0} \text { is } \\
\text { rejected }\end{array}$ \\
\hline Control & 24 & 65,67 & 3,215 & & \\
\hline
\end{tabular}

It appears that so $\mathrm{H}_{0}$ is rejected, so it can be concluded that learning DL by using interactive multimedia is more effective than DL learning without using interactive multimedia. This is in line with Hardiyanto's research [18] and Andrius [20] that learning with interactive multimedia is more effective than learning without using interactive multimedia.

\section{CONCLUSIONS AND SugESTIONS}

The conclusion that can be drawn from the above results is that learning of DL model on Pythagoras theorem material by using interactive multimedia is more effective than DL model learning on Pythagoras theorem material without using interactive multimedia.

Suggestions from the authors, junior high school students are not fully able to think abstract. But they can already be invited and trained in that regard. For that, make it a habit to learn what makes them active. 


\section{ACKNOWLEDGMENT}

Acknowledgments of the authors convey to Dr. Imam Sujadi, M.Si., and Dr. Ir. Ikrar Pramudya, M.Si. as a lecturer supervising the author's thesis at Sebelas Maret University Surakarta. And thank you not to forget the author convey to the Head of MTs Al-Furqon Sanden which has given the author the opportunity to conduct research in his school.

\section{REFERENCES}

[1] Programme for International Student Assessment PISA. Results in Focus (www.oecd.org/pisa). 2016.

[2] Mullis I.V.S., Martin M.O., Foy P. and Arora A. "TIMMS 2011 International Result in Mathematics" (Chestnut Hill: TIMSS \& PIRLS International Study Center). 2012.

[3] Salinan Permendikbud No 22 Tahun 2016 Tentang Proses Pendidikan Dasar dan Menengah (bsnp-indonesia.org)

[4] Balm A.G. "The Effect of Discovery Learning on Students' succsess and Inquiry Learning Skills". Eurasian Journal of Education Research, Issue 35, 1-20. 2009

[5] Syahbana A. "Peningkatan Kemampuan Berpikir Kritis Matematis Siswa SMP Melalui Pendekatan Contextual Teaching and Learning". Edumatica. 2(1), 45-57. 2012.

[6] Fitriani H. "Pengaruh Model Discovery Learning disertai Media Gambar Terhadap Kognitif siswa kelas VII MTs Bahrul Ulum Tahun Pembelajaran 2014/2015" Jurnal Pendidikan 1. 2014.

[7] Milavanovic M, Durdica T, and Aleksander M. Multimedia Approach in "Teaching Mathematics - Examples of Interactive Lesson From Mathematical Analisis and Geometry". Interactive Multimedia, 6, 112116. 2012.

[8] Mayer R.E. "Multimedia Learning Prinsip-prinsip dan Aplikasinya" (Yogyakarta : Pustaka Pelajar). 2009.
[9] Nusir S, Izzat A, Mohammed A.K., and Fatima S. "Studying the Impact of using Multimedia Interactive Programs at Children Ability to Learn Basic Math Skills” Acta Didactica Bapocensia vol 5, pp.17-32. 2012.

[10] Amine A.T., Chellali B., and Boutkhil G. "Using Multimedia to Motivate Students in EFL Classrooms : A Case Study of English Master's Students at Jijel University" Algeria Malaysian Journal of Distance Education, vol 14, pp.63-81. 2012.

[11] Ampa A.T. "The Implementation of Interctive Multimedia Learning Materials in Teaching Listening Skills" English Language Teaching. 8 56-62. 2015.

[12] Daryanto. "Media Pembelajaran, Peranannya Sangat Penting dalam Mencapai Tujuan Pembelajaran” (Yogyakarta : Gava Media). 2016.

[13] Mishra S, \& Ramesh C.S. "Interactive Multimedia in Education and Training” India Idea Group Publising. Vol 6, pp. 115-122. 2004.

[14] House J.D. "Mathematics Beliefs and Achievement of Elementary School Students in Japan and the United States : Result From the Third International Mathematics and Science Study" The Journal of Genetic Psychology. Vol 167, pp.31-45.2006.

[15] Arsyad A “Media Pembelajaran”. (Jakarta : PT Raja Grafindo) 2013

[16] Aldoobie N. "ADDIE Model” vol 5 no 6 (USA : American International Journal of Contemporary Research). 2015.

[17] Cheung L. "Using ADDIE Model of Instructional Design to Teach Chest Radiograph Interpretation” Journal of Biomedical Education. 2016.

[18] Hardiyanto E L, Budiyono, and Budi S "Pengembangan Multimedia Interaktif untuk Pembelajaran Materi Pokok Balok Siswa SMP Kelas VIII" Jurnal Elektronik Pembelajaran Matematika. vol 3 pp.215-221. 2015.

[19] Budiyono. "Statistika untuk Penelitian" (Surakarta : UNS Press). 2009.

[20] Adrianus I W, I Yuda S, I Made C, and I Made C "Pengembangan Multimedia Pembelajaran Matematika Berpendekatan Kontekstual untuk Siswa Kelas VIII di SMP Negeri 4 Singaraja” e-Jour Program Pascasarjana Universitas Ganesha Prodi Teknologi Pembelajaran. vol 3 pp.12-21. 2013. 